\title{
Nie tylko do archiwum. Wokół literackiego zdarzenia i filmowego dokumentu
}

\author{
Piotr Pławuszewski
}

Nie wykracza poza truizm stwierdzenie, że kultura filmowa, już od najwcześniejszych etapów swego rozwoju, na wielu płaszczyznach przenikała się z kulturą literacką. Ta ostatnia nierzadko pełniła w tym układzie funkcję edukatora (podpowiadając między innymi konwencje opowiadania, strategie narracyjne czy chwyty dramaturgiczne), dostarczycielki historii (olbrzymia przestrzeń zagadnień adaptacyjnych), ale też zwierciadła dla wielu zagadnień wykraczających poza sam wytwór pracy artystycznej (czego przykładem choćby refleksja nad publicznością literacką i filmową). Szeroka, ponad 100-letnia perspektywa czasowa pozwala jednak zauważyć, że z pewnością nie mamy tu do czynienia z jednostronnym przepływem „wartości”. Film, z dekady na dekadę wzbogacając środki wyrazu (zainspirowane teatrem, malarstwem czy literaturą, ale i prymarnie wykreowane dla swego medium ${ }^{1}$ ), uczył inne sztuki choćby tego, jak w szybki i twórczy sposób reagować na społeczno-polityczną teraźniejszość - zarówno w wariancie fabularnym (szybko przekonał o tym widownię Charlie Chaplin w Dzisiejszych czasach [1936]), animowanym (np. radzieckie produkcje propagandowe z lat dwudziestych i trzydziestych), jak i dokumentalnym (vide kroniki filmowe w okresie II wojny światowej, między innymi amerykańska The March of Time i kanadyjska The World in Action). Przy ostatniej z wymienionych konwencji przedstawieniowych warto zatrzymać się na dłużej - wracając jednocześnie do szeroko pojętej kultury literackiej. Z kilku powodów tak zaprojektowana płaszczyzna spotkania zdaje się nieoczywista. Po pierwsze, jakkolwiek dalekie od jednomyślności były i są definicje kina dokumentalnego (trudno tu o rekapitulację toczonych od niemal

\footnotetext{
${ }^{1}$ W znanym, ciekawie problematyzującym kwestię wypowiedzi kinematograficznej eseju Kino poezji Pier Paolo Pasolini zapisał: „Prawdą jest, że w trakcie niemal pięćdziesięciu lat istnienia kino wypracowało swego rodzaju słownik kinematograficzny, tj. ustaliła się pewna konwencja, która jest o tyle interesująca, że ma wymiar przede wszystkim stylistyczny, a dopiero w drugiej kolejności - gramatyczny”. P.P. Pasolini, Kino poezji, [w:] tegoż, Po ludobójstwie. Eseje o języku, polityce i kinie, przeł. M. Salwa, Warszawa 2012, s. 150.
} 
początku XX wieku dyskusji na ten temat), to ciągle żywa na gruncie fabuły i animacji tradycja filmowego adaptowania literatury pozostaje poza jego granicami ${ }^{2}$. Po drugie, nie ignorując faktu, iż między literaturą (zwłaszcza w odmianie „non-fiction”) a kinem faktów również w jakimś stopniu dochodziło na przestrzeni dekad do wzajemnej inspiracji, to mimo wszystko należałoby podkreślić zwiększoną w stosunku do filmu fabularnego „samodzielność” rozwoju form dokumentalnych. Jak ujął to Jack Ellis: „Film dokumentalny, jako forma artystyczna, to technika i styl, które zrodziły się na gruncie ruchomych obrazów"3 (przy czym, zaraz dodaje badacz, trudnym do zmarginalizowania uzupełnieniem obrazu są tu między innymi osiągnięcia dziewiętnastowiecznej fotografii). Po trzecie, o ile zauważalnym zjawiskiem jest powstawanie książek na bazie istniejących wcześniej filmów fabularnych (ang. novelization ${ }^{4}$ ), o tyle kino faktów podlega temu procesowi znacznie rzadziej (jednym z polskich wyjątków potwierdzających regułę jest Dziedzictwo [1993] Henryka Grynberga, pokłosie dokumentalnego arcydzieła Pawła Łozińskiego Miejsce urodzenia [1992]). Rodzi się zatem pytanie, gdzie z większym powodzeniem szukać wspomnianego miejsca spotkania: kultury literackiej i filmowego dokumentu. Przychodzi do głowy refleksja, by podkreślić w tym miejscu nieodzowną (choć różnie realizowaną) funkcję tego ostatniego, jaką jest - dokumentowanie/rejestrowanie niezainscenizowanej rzeczywistości ${ }^{5}$. A przecież takq rzeczywistość zapewniajq także niektóre przejawy kultury literackiej, choćby te o charakterze "niepowtarzalnej” w danym kształcie zdarzeniowości. Slam poetycki i spotkanie z pisarzem - oto takie „zdarzenia”, w oczywisty sposób od siebie różne, ale też skłaniające, w ramach zarysowanej problematyki, do nakreślenia pewnych analogii. Niech oświetla je (eksplikowana w toku rozważań) ogólniejsza refleksja, że filmowy dokument - jeśli tylko stojąca za nim intencja nie ogranicza się do chęci zwykłej "archiwizacji” rzeczywistości - może skutecznie wykroczyć poza rolę dodatku w kierunku zdarzenia i stać się jego uważnym interpretatorem.

Na początek wyrastający z lat osiemdziesiątych slam poetycki: „pierwsze wydarzenie poetyckie, które połączyło elementy przedstawienia, piśmiennictwa, rywalizacji oraz udziału publiczności”6. Hybrydyczny charakter slamu, dynamika zarówno ludzkiej zbiorowości, jak i każdorazowego przed nią występu konkretnego człowieka, dramaturgia wpisana w formułę współzawodnictwa (nie mówiąc po prostu o potencjalnych walorach literackich prezentowanej

\footnotetext{
2 Intrygującym „wariantem” (ciągle jednak - rzadkim) tak pomyślanego zetknięcia literacko-filmowego jest sytuacja, gdy konkretna książka staje się dla przyszłego dokumentu bezpośrednią inspiracją (przykładowo: dzieło amerykańskiego historyka, Andrew Wiesta, Boys of '67: Charlie Company's War in Vietnam [2012] dało początek dokumentowi Brothers in Wars [2014] w reżyserii Liz Reph; analogiczny proces miał miejsce w przypadku książki Margaret Atwood Payback: Death and the Shadow Side of Wealth [2008] i filmu Jennifer Baichwal Payback [2012]).

${ }^{3}$ Zob. J. Ellis, The Documentary Idea: A Critical History of English-Language Documentary Film and Video, Englewood Cliffs, N.Y. 1989, s. 1-14.

4 J. Mahlknecht, The Hollywood Novelization: Film as Literature or Literature as Film Promotion?, „Poetics Today” 2012, nr 22, s. 137-168.

${ }^{5}$ Piszący te słowa ma pełną świadomość, w jak dużym stopniu każda składowa tak skonstruowanego zdania otwiera się na mnogość wątpliwości i zagadnień bardziej szczegółowych. Jak hierarchizować (jeśli w ogóle) funkcje wpisane $\mathrm{w}$ filmowy dokumentalizm? Kiedy rejestracja przy użyciu kamery przestaje być wyłącznie mechaniczną notacją pewnego fragmentu realności, a zyskuje miano dzieła filmowego? Czy „niezainscenizowana rzeczywistość" implikuje tezę, iż jakiekolwiek działania inscenizacyjno-aranżacyjne są w kontekście documentary wykluczone? Niemniej jednak, na potrzeby tego tekstu, chcąc naświetlić bardzo konkretne zjawisko z pogranicza literacko-filmowego, w punkcie wyjścia przyjęto rozumienie dokumentu niejako bazowe, w kolejnych akapitach niuansowane wtedy, gdy zdaje się tego wymagać podejmowany wątek.

${ }^{6}$ M. Bañales, Slam Poetry, [w:] Encyclopedia of Activism and Social Justice, t. 3, red. G.L. Anderson, K. Herr, Thousand Oaks, CA 2007, s. 1290.
} 
twórczości) - wszystko to bez wątpienia ciekawe tworzywo dla dokumentalnej kamery. Co istotne, może ona, towarzysząc poetom-zawodnikom, wykroczyć poza rolę wyłącznie rejestratora-archiwisty. Dowiódł tego Paul Devlin w dokumencie SlamNation (1998), pełnometrażowej relacji z National Poetry Slam (Portland, Oregon 1996), wielodniowej imprezy, skupiającej uczestników z różnych zakątków Stanów Zjednoczonych. Pomijając wartość „humanistyczną” filmu (slamowe współzawodnictwo nie wyklucza tu szacunku dla poetyckiego rywala), warto zwrócić uwagę na trzy sprawy: (1) użycie więcej niż jednej kamery pozwala na etapie montażu niejako podążyć za słowem mówionym (i prędkość wypowiadania go oddać na przykład za pomocą zwiększonej liczby cięć); (2) to właśnie filmowemu dokumentowi udaje się chwilami uchwycić jeden z ważniejszych aspektów poetyckiego slamu, jakim jest raczej swobodny stosunek do zapisanego tekstu - na powiązane z tym spostrzeżeniem ujęcie zwrócił uwagę w swej recenzji SlamNation Roger Ebert: „W swej istocie, poetyckie slamy są sztuką performatywną, nie literacką. Jest takie ujęcie z nowojorskim wydawcą literackim, który wzdycha przy stercie slamowych rękopisów, zdając sobie sprawę, że czasami poezja ta źle znosi przeniesienie na zadrukowaną stronę"7; (3) taki film, jak SlamNation, zwłaszcza we fragmentach z występami poetów-zawodników, potrafi nie tyle usunąć, co zminimalizować stratę wpisaną w sytuację odbioru poetyckiego slamu, gdy jest on (odbiór) zapośredniczony - widz, mając oczywiście świadomość „skonstruowanego widzenia” (rodzaj obiektywu, kąt patrzenia, montaż itp.), jest wówczas bliżej wielu istotnych „jakości” zdarzenia, niż gdyby był w sytuacji przekazu wyłącznie audialnego. Tak o niezbywalnej wartości wizualnego pierwiastka w doświadczeniu slamu poetyckiego pisze Susan B.A. Somers-Willett: „Nie przede wszystkim dzięki aktowi słuchania zwiększyło się grono entuzjastów poetyckiego slamu; choć płyty CD i pliki MP3 są popularnym sposobem dokumentowania slam poetry, to najlepszą okolicznością odbioru jest tu występ na żywo. (...) Publiczność nie tylko słucha tych wierszy, ale reaguje na całościowy akt ich wypowiadania, czasami od razu reagując zwrotnie w kierunku poety czy gospodarza imprezy: przez aplauz, złośliwe syczenie albo wykrzykiwane komentarze. Widzowie odbierają prezentowany wiersz, doświadczając, jak poeta się rusza, jak wygląda, jak brzmi i fizycznie ucieleśnia swoją poezję".

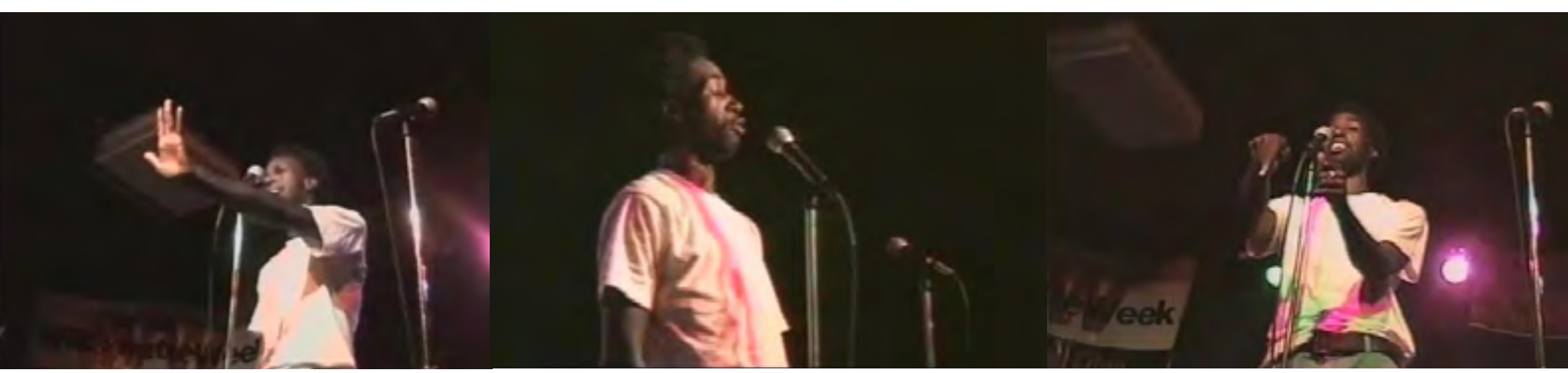

Kadry z filmu SlamNation P. Devlina

${ }^{7}$ R. Ebert, SlamNation (<http://www.rogerebert.com/reviews/slamnation-1998> [dostęp: 6.06.2016]).

${ }^{8}$ S.B.A. Somers-Willett, The Cultural Politics of Slam Poetry: Race, Identity, and the Performance of Popular Verse in America, Michigan 2009, s. 17. 
Filmowe dokumentowanie poetry slam (ale też takiego typu „literackiego zdarzenia”, jakim jest spotkanie z pisarzem, o czym więcej za moment) rodzi zasadnicze pytanie o status audiowizualnego materiału. Na przykład: w tkankę łączącego różne konwencje przedstawieniowe filmu Baczyński (2013) Kordiana Piwowarskiego wplecione zostały ujęcia ze slamu poetyckiego: zorganizowano go w Warszawie w roku 2011, okazją była 90. rocznica urodzin tytułowego poety, uczestnicy prezentowali przed publicznością jego wiersze. To z pewnością istotny element filmu, bo w niedosłowny sposób pozwala zastanowić się, czy (cytując słowa padające ze sceny w kierunku widowni): „ta poezja jeszcze dzisiaj żyje, czy do was jakoś przemawia”. Dla tego tekstu istotniejsze jest jednak pytanie, czy (jeśli w ogóle) owa rejestracja warszawskiego slamu mogłaby funkcjonować poza Baczyńskim Kordiana Piwowarskiego jako autonomiczne dzieło filmowe - jako coś więcej, niż „zdjęcia czysto kronikalne, w których chodzi jedynie o najbanalniejsze zarejestrowanie złożenia wieńca czy podanie ręki przez dostojnika" kwestia bardzo złożona, zwłaszcza w kontekście wieloaspektowej materii kina faktów. Na potrzeby tego tekstu, pozostańmy przy cennym (choć przecież dalekim od prostych wskazań) rozpoznaniu Kazimierza Karabasza:

Jeżeli [dokumentalne zdjęcia - P.P.] nie mają być zdawkową notacją faktów, muszą mieć przynajmniej dwie cechy: być profesjonalnie sfotografowane (plan, kąt patrzenia) oraz posiadać swoją „energię wewnętrzną”. Pierwsza cecha jest oczywista, a druga? Trzeba zachowanie człowieka (ludzi) bardzo uważnie śledzić w trakcie ujęcia. Kiedy jego energia wewnętrzna się „nasyciła”? To sprawa wyczucia temperatury toczącego się zdarzenia... Operator może chcieć za wcześnie wyłączyć kamerę - reżyser musi czuwać (i do tego nie dopuścić). Mogą oczywiście zrobić następne ujęcie. Ale to już będzie inny moment. O czymś innym ${ }^{10}$.

- dochodzi do tego oczywiście etap montażu, kiedy zebranemu materiałowi „teraz dopiero należy nadać jakiś kształt"11. Biorąc to wszystko pod uwagę, można wyobrazić sobie, że slamowo-poetyckie partie Baczyńskiego - ze swym uważnym przypatrywaniem się twarzom (i widocznym na nich emocjom), zróżnicowanym perspektywom spojrzenia, kolorystycznym ograniczeniem do czerni i bieli, starannym spleceniem ścieżki dźwiękowej i obrazowej - mogłyby zaistnieć jako osobny film dokumentalny. Film zawężający swój świat przedstawiony do miejsca poetyckiej rywalizacji, w nim tylko szukający uzasadnienia dla swego kształtu i ewokowanego sensu. Przykładem tak skonstruowanego dzieła jest nakręcony w Los Angeles krótki metraż Poetry Slam (2005, reż. Jordi Ortega). Jednocześnie, należy podkreślić, że znacznie częstszą praktyką jest ta, gdy udokumentowane zdarzenie-slam poetycki staje się elementem większej całości, na którą składają się również np. wywiady do kamery czy sceny z życia codziennego bohaterów (szeroko zakrojony „horyzont” spojrzenia zapewniają między innymi niemiecki dokument Dichter und Kämpfer: Das Leben als Poetryslammer in Deutschland [2012, reż. Marion Hütter] i bardzo intrygujące, podkreślające terapeutyczny wymiar „mówionej poezji” dzieło amerykańskich twórców, Grega Jacobsa i Jona Siskela, Louder Than a Bomb [2010]).

\footnotetext{
${ }^{9}$ K. Karabasz, Odczytać czas, Łódź 2009, s. 20.

${ }^{10}$ Tamże.

${ }^{11}$ Tamże, s. 24.
} 


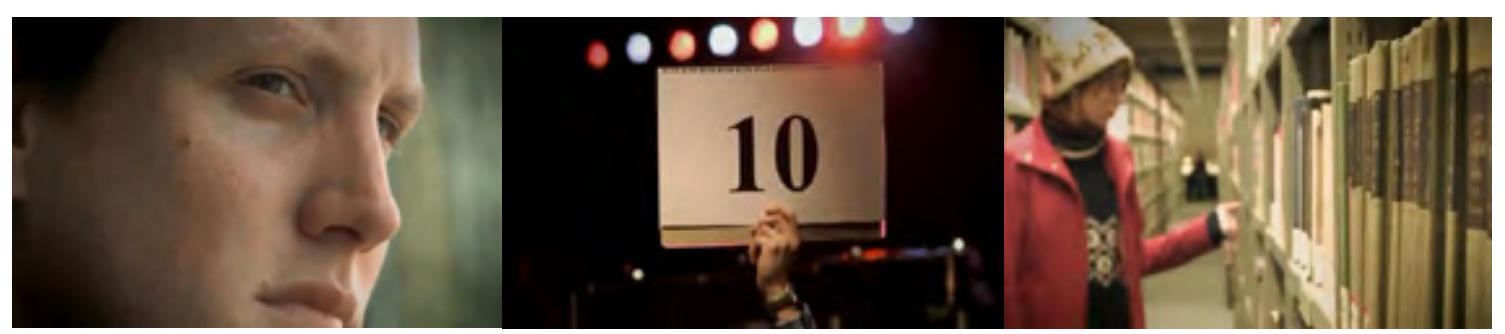

Kadry z filmu Dichter und Kämpfer: Das Leben als Poetryslammer in Deutschland M. Hütter

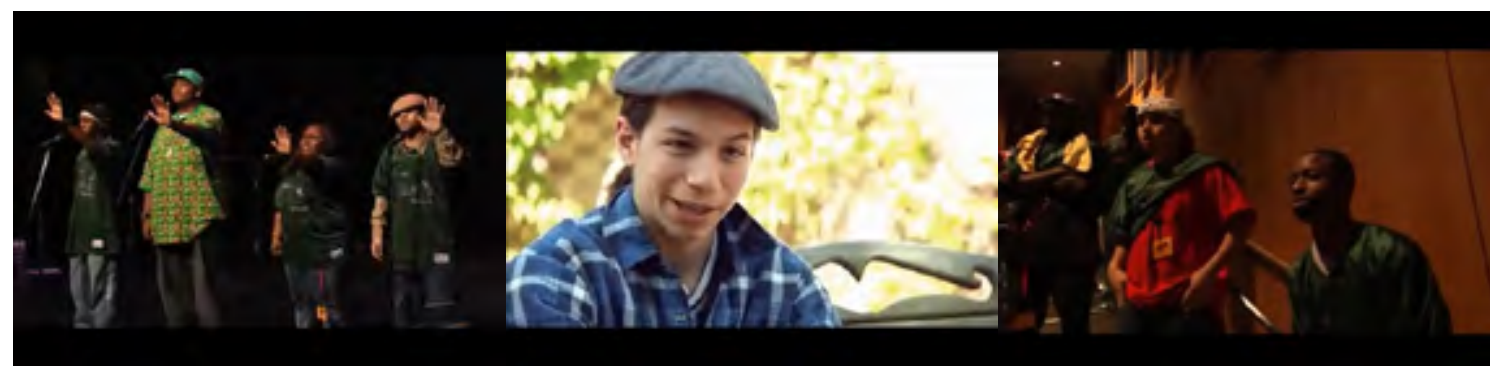

Kadry z filmu Louder Than a Bomb G. Jacobsa i J. Siskela

Niezależenie od formy, jaką przybiera spotkanie slamu poetyckiego i filmowego dokumentu, jest ono wartym badawczej refleksji (nierzadko ciekawym artystycznie i bogatym w znaczenia) faktem. Innym zdarzeniem z przestrzeni kultury literackiej o, zdawałoby się, podobnym potencjale - ale znaczenie dłuższej tradycji - w zetknięciu z dokumentalną kamerą jest spotkanie autorskie z pisarzem: na targach książki, w związku z wydaniem nowego dzieła, w ramach literackiego festiwalu itd. „Zdawałoby się”, bo ów przeczuwany potencjał - przynajmniej w odniesieniu do rodzimej kinematografii, najlepiej rozpoznanej dla piszącego te słowa - nigdy nie został w pełni wykorzystany.

Po pierwsze, powraca tu wiele zagadnień, które wymagały wspomnienia już w kontekście slamu poetyckiego. Jednym $\mathrm{z}$ nich jest charakter zarejestrowanego materiału - $\mathrm{w}$ dobie powszechności zapisu cyfrowego nie może dziwić fakt, iż od około dekady niemal każdy festiwal literacki, w różnym ilościowo wymiarze, dokumentuje audiowizualnie swój przebieg. Organizowane w ramach imprezy spotkania autorskie nie są wyjątkiem - tyle że w ogromnej większości przypadków mamy tu do czynienia z prostą, statyczną notacją, niewykraczającą funkcjonalnie poza (cenną skądinąd) chęć archiwizacji danego zdarzenia. Po drugie, wzmiankowana statyka operatorska ma swe oczywiste źródło w specyfice spotkania autorskiego: uczestnicy („po obu stronach stołu”) nie zmieniają zwykle swego położenia, dość przewidywalne są też zwyczajowe komponenty takiej sytuacji (rozmowa prowadzącego z literatem, głośna lektura wyimków z jego twórczości, pytania od publiki, ew. podpisywanie książek). Nie brak w audiowizualnych archiwach imprez literackich takich przykładów, gdy ustawiona na statywie kamera nie tylko nie zmienia swego położenia w przestrzeni, ale też nie wykonuje żadnych ruchów, choćby poziomej panoramy między autorem a publicznością (ten pierwszy - inaczej niż w demokratycznie urządzonym poetyckim slamie bezapelacyjnie odgrywa tu wiodącą rolę). Po trzecie, podkreślony wcześniej, niejako immanentny walor dramaturgiczny slam poetry nie ma prostego odpowiednika w ramach spotkania z pisarzem (które w standardowej formule nie obrazuje wznoszenia się ku punktowi kulminacyjnemu, jakim jest na przykład rozstrzygnięcie współzawodnictwa; tu pierwiastek zaskoczenia może brać się po 
prostu z niespodziewanego przebiegu zdarzeń $\left.{ }^{12}\right)$. Biorąc pod uwagę już choćby te trzy aspekty, można zastanawiać się, czy twierdzenie o niewykorzystanym potencjale spotkania dokumentu ze zdarzeniem literackim nie jest w tym wypadku przesadzone. Kilka refleksji na ten temat.

W udokumentowanym filmowo spotkaniu autorskim (jak i slamie poetyckim) bez wątpienia tkwi potencjał naukowy. Na poziomie niejako podstawowym: to zawsze, nawet w najbardziej surowym kształcie, źródło historyczne (inspirująco o filmie jako świadectwie historycznym, na szeroko zarysowanym tle zagadnienia wizualności, pisał m.in. Peter Burke ${ }^{13}$ ). Idąc dalej, ów potencjał, jakkolwiek ogólnikowo to brzmi, zawiera się w rejestracji wycinka pewnej rzeczywistości społeczno-kulturowej, która może być cennym materiałem badawczym dla praktyków socjologii/antropologii wizualnej. Nie niwelują tego wniosku (stanowiące de facto inną problematykę) ani trudności ze zdefiniowaniem filmu socjologicznego czy dokumentu etnograficznego, ani dyskusje wokół traktowania zapisów audiowizualnych jako wypowiedzi naukowej równoprawnej z tekstem pisanym. „Wykorzystywanie mediów wizualnych i praktyk reprezentacji (jako uzupełnienie bezpośredniej obserwacji) w roli środków pozyskiwania trwałego aczkolwiek nieuchronnie zapośredniczonego - dostępu do naturalnie występujących zjawisk lub artefaktów kulturowych stało się dziś nieco mniej obce praktyce naukowej"14. Opinia Luca Pauwelsa, odniesiona do omawianej tu kwestii, pozwalałaby sądzić, że spotkanie autorskie jeśli udokumentowane z przynajmniej podstawową wiedzą na temat warsztatu filmowego oraz intencją naukową (czy - jak pisze Jerzy Kaczmarek w kontekście socjologii - z „kompetencją socjologiczną"15) - może przynieść ze sobą ciekawe poznawczo efekty, dotyczące np. interakcji między widownią a twórcą czy stylów prowadzenia z nim rozmowy przez "gospodarza" spotkania. Zważywszy zaś na fakt, że olbrzymia większość takich dokumentacji ograniczała i ogranicza się do wspomnianej już prostej archiwizacji (dokonywanej bez zamierzeń naukowych), cenne zdaje się przytoczenie innego fragmentu rozważań Jerzego Kaczmarka:

[...] film socjologiczny może również powstać z materiału zastanego, którego sam socjolog nie jest autorem, lecz wykorzystał istniejące już wcześniej ujęcia bądź powstały one na jego polecenie. Jednakże rozstrzygające jest tutaj to, że badacz nadaje temu materiałowi odpowiednią strukturę i w drodze interpretacji, na bazie swojej wiedzy socjologicznej, tworzy odrębną wypowiedź naukową ${ }^{16}$.

Potencjał naukowy to jednak nie wszystko. Inną z praktykowanych dróg twórczego użycia audiowizualnego zapisu spotkania autorskiego jest bowiem uczynienie go składową większej struktury: filmu dokumentalnego (zrealizowanego bez intencji stricte badawczych). Właśnie: składową. Mowa

\footnotetext{
${ }^{12}$ „Siwy pan z pierwszego rzędu patrzył w sufit, dziewczęta wpatrywały się we mnie. Kierowniczka klubu siedziała sztywno, miała zmarszczone brwi, bibliotekarka w zielonym sweterku cały czas, jak czytałem, uśmiechała się. W pewnej chwili jakiś chuligan otworzył drzwi, wsunął głowę i powiedział: - Łeee... Na sali i w korytarzu wybuchł śmiech. Młoda kierowniczka klubu wyszła na korytarz, a bibliotekarka wstała i uciszyła salę wzrokiem. Czytałem dalej, a kiedy skończyłem, rozległy się zaraz oklaski”. K. Filipowicz, Moja kochana, dumna prowincja, [w:] tegoż, Biały ptak i inne opowiadania, Kraków 1973, s. 277.

${ }^{13}$ Zob. P. Burke, Naocznosć. Materiały wizualne jako świadectwo historyczne, przeł. J. Hunia, Kraków 2012 (szczególnie rozdziały: Narracje wizualne [s. 164-182]; Od świadka do historyka [s. 183-194]).

${ }^{14}$ L. Pauwels, Zwrot wizualny $w$ badaniach $i$ komunikacji wiedzy. Kluczowe problemy rozwijania kompetencji wizualnej w naukach społecznych, przeł. M. Frąckowiak, [w:] Badania wizualne w działaniu, red. M. Frąckowiak, K. Olechnicki, Warszawa 2011, s. 22.

${ }^{15} \mathrm{~J}$. Kaczmarek, Zobaczyć społeczeństwo. Film i wideo w badaniach socjologicznych, Poznań 2014, s. 203.

${ }^{16}$ Tamże, s. 202.
} 
bowiem o literackim zdarzeniu, które bardzo często podlega wizualno-dźwiękowej archiwizacji, nierzadko współtworzy materię ekranowego portretu pisarza, ale właściwie nie występuje jako sytuacja godna autonomicznego dzieła. Może to zastanawiać tym bardziej że te „niesamodzielnie” funkcjonujące fragmenty wcale nie dowodzą, iż ich walor sensotwórczy wyczerpałby się poza szerszym kontekstem. Trzy polskie przykłady: w Dziennik pisany pod wulkanem (1995) Andrzeja Titkowa włączone są między innymi ujęcia z kilku spotkań z Gustawem Herlingiem-Grudzińskim, które odbyły się w czasie jego wizyty w Polsce w 1994 roku. Reżyser nie lekceważy słów bohatera - ale też w pełni korzysta z możliwości medium, by niekiedy oddać kumulowaną w czytelnikach przez lata chęć nawiązania kontaktu z pisarzem (na jego wizerunek nałożono więc jednocześnie kilka ścieżek dźwiękowych z pytaniami), a innym razem podążyć za przedmiotem (powracająca drewniana laska lub pudełko $z$ tabletkami). Już przez te wizualno-audialne detale ze spotkań autorskich przebija coś istotnego - choćby przeczucie, jak długo musieli na siebie czekać pisarz i jego polscy odbiorcy (w 1991 roku Herling-Grudziński przybył do Polski po raz pierwszy po 52 latach nieobecności).

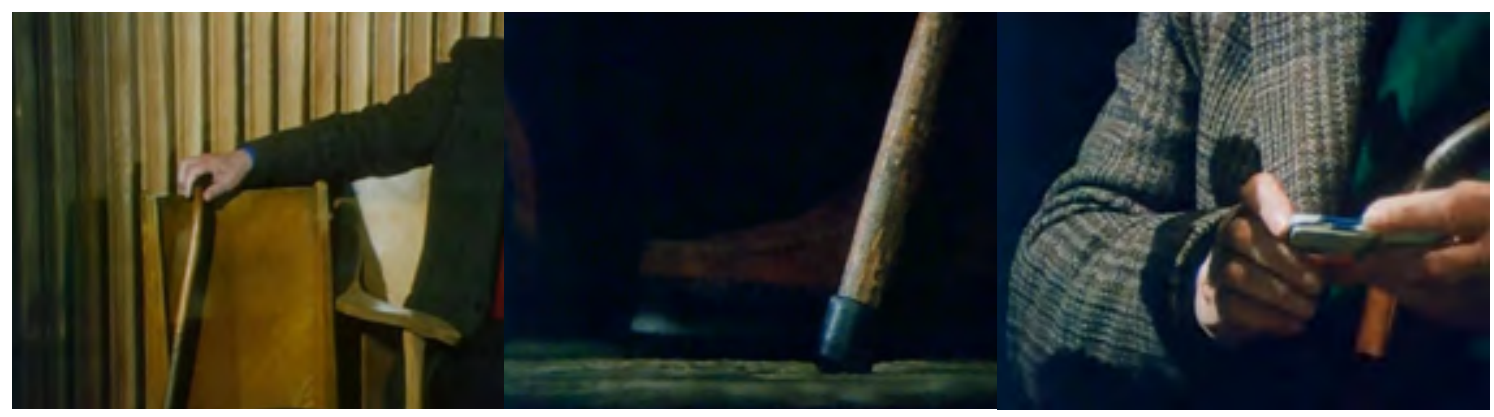

Kadry z filmu Dziennik pisany pod wulkanem A. Titkowa

Na innej zasadzie opiera się użycie analogicznych ujęć w Radości pisania (2005) Antoniego Krauzego, dokumencie poświęconym Wisławie Szymborskiej. Spotkanie z poetką, prowadzone przez Teresę Walas i Ryszarda Krynickiego, odbywa się niedługo przed podróżą do Sztokholmu i odbiorem Nagrody Nobla. Tu najważniejsze są słowa bohaterki - wyraźnie świadczące o tym, że powstała sytuacja jest dla niej niemałym brzemieniem, a na pewno próbą, by nadal być „osobą”, nie zaś „osobistością". Rzecz ciekawa: to samo spotkanie powróci na kilka sekund z obrazem poetki podpisującej książki oraz - z niechęcią i dezaprobatą reagującej na jakiegoś kamerzystę, który podchodzi bardzo blisko stolika. Łatwo przypuszczać, że tak korespondujące ze sobą ujęcia - z oświetlającymi się nawzajem elementami werbalnymi i niewerbalnymi - same mogłyby stać się tworzywem bardzo ciekawego dokumentu, choćby na temat wspomnianej, uporczywej chęci pozostania „osobą”. Taka myśl to całkiem logiczny pomost do ostatniego przykładu, tym razem związanego ze Sławomirem Mrożkiem. „Ja odrzucam zasadę policyjną: że przesłuchiwany siedzi na krześle albo stoi, ekipa policyjna świeci mu w oczy i on musi odpowiadać na każde pytanie i nie ma prawa nie odpowiadać" - mówił pisarz w Sławomir Mrożek przedstawia (1997) Pawła Łozińskiego, nie kryjąc się z niechęcia do formuły „pytanie-odpowiedź”. Większość dokumentów poświęconych pisarzowi, jakby chcąc zniwelować tę okoliczność, bazuje na zasadzie kompilacji, mieszając wypowiedzi bohatera i ludzi go znających $\mathrm{z}$ archiwaliami czy materiałem obserwacyjnym. Wspomniany Paweł Łoziński cały swój dokument nakręcił na meksykańskim ranczu pisarza. Powstał z tego portret niezwykle kameralny, bardzo odległy od założeń i aury takiego wydarzenia, jakim jest m.in. spotkanie autorskie. Pojawia się jednak Mrożek w tym akapicie nieprzypadkowo, mimo że specyficzny może wydać się kontekst: chodzi bowiem o udostępnioną w Internecie przez Wydawnictwo Literackie relację z pobytu dra- 
maturga w Polsce w marcu 2012 roku. Założenie musiało być proste: kilka dokumentalnych migawek z podpisywania książek w Katowicach i Krakowie (plus uroczystość wręczenia w tym ostatnim mieście Orderu Ecce Homo). Mimo że nie mamy tu do czynienia z „pełnowymiarowym” spotkaniem autorskim i zupełnie niepotrzebnie dodano podkład muzyczny, warte docenienia są inne walory tej krótkiej produkcji, przede wszystkim jej wymiar obserwacyjny. „Przez moment zaglądamy w życie takim, jakim jest ono przeżywane. Społeczni aktorzy wchodzą ze sobą w relacje, ignorując twórców filmowych. Często postacie są związane naglącymi potrzebami i uwikłane we własne kryzysy. Wszystko to wymaga ich uwagi i odciąga ją jednocześnie od obecności twórców. Sceny, podobnie jak w filmie fabularnym, ujawniają najczęściej aspekty charakteru i indywidualności”"17 - pisze o obserwacyjnym trybie filmowego dokumentu Bill Nichols, jednocześnie podając celną charakterystykę tych ujęć, kiedy w Katowicach kolejni czytelnicy proszą Sławomira Mrożka o wpis do książki. Ktoś mówi o wspólnym znajomym, ktoś jest z Japonii, ktoś zdradza „obecność Mrożka” na maturze, wreszcie: ktoś nieśmiało pyta o możliwość podania ręki. A pisarz, przy całym swym wycofaniu, odpowiada na te gesty z sympatią i cierpliwością. Dyskretna obserwacja jest tu nieoceniona - bo to dzięki niej widz ma szansę przyjrzeć się „społecznym aktorom” (pisarzowi i czytelnikom) oraz ich jakże zniuansowanym relacjom (podziw, trema, radość, zaciekawienie...). Tak oto kilka ujęć reporterskiej z ducha relacji pozwala podtrzymać opinię, iż spotkanie autorskie jest dla reżysera-dokumentalisty potencjalnym źródłem wielu filmowych inspiracji.

Próbując szkicowo uogólnić i podsumować: wartym namysłu punktem przecinania się ścieżek kultury literackiej i filmowego dokumentu jest niepowtarzalna w tym samym kształcie zdarzeniowość, w tekście uobecniona pod postacią slamu poetyckiego i spotkania autorskiego. Oba „zdarzenia” - choć tak odmienne w swej specyfice - w równym stopniu otwierają się na możliwości dokumentalnej kamery, której funkcja nie musi polegać ani na zaledwie „notowaniu” rzeczywistości, ani poddawaniu jej różnego typu zabiegom subiektywizacji ${ }^{18}$. Ślady rozsiane po wielu filmowych przykładach podpowiadają, że efektywną metodą docierania do wzmiankowanych zjawisk jest uważna obserwacja, wyczulenie na obraz, ale też dźwięk. Taki zaopatrzony w kamerę obserwator może wiele dostrzec i zarejestrować: choćby temperaturę/odbiór słowa (zarówno na poetyckim slamie, jak i w trakcie spotkania z pisarzem). Wiele jednak jeszcze do zrobienia - prezentowany tekst to zaledwie wycinek szerszego horyzontu zagadnień, a i sami dokumentaliści zdają się ciągle tylko połowicznie wierzyć w filmowy potencjał przywołanych tu fenomenów literackiego mikrokosmosu.

Nie należy do nich Gur Bentwich, który kilka lat temu postanowił towarzyszyć pisarzowi Edgarowi Keretowi w czasie serii nowojorskich spotkań z czytelnikami. Powstał z tego dokument What Animal Are You? (2012), którego podstawowym spoiwem są właśnie ujęcia z owych spotkań. Często nieostre, lekko rozedrgane, z Keretem głośno czytającym, śmiejącym się, opowiadającym niekoniecznie o książkach. Jako całość układają się te brudnopisowe zapiski filmowe w klucz do literackiego świata o nieprzeciętnej wartości. I trudno pozbyć się wrażenia, że to w tym samym stopniu zasługa pisarza, co tworzącego jego portret dokumentalisty.

\footnotetext{
${ }^{17}$ B. Nichols, Typy filmu dokumentalnego, przeł. M. Heberle, D. Rode, [w:] Metody dokumentalne w filmie, red. D. Rode, M. Pieńkowski, Łódź 2013, s. 23.

${ }^{18}$ Zob. tamże, s. 37-42 (rozważania B. Nicholsa na temat trybu performatywnego w dokumencie).
} 


\title{
SŁOWA KLUCZOWE:
}

\section{film dokumentalny}

\section{interpretacja}

\section{O D A T E K}

\section{kamera}

\section{spotkanie}

\section{obserwacja}

\begin{abstract}
AbSTRAKT:
Artykuł jest próbą przyjrzenia się miejscu spotkania: kina dokumentalnego i kultury literackiej, pojmowanej tu w kontekście „zdarzeniowości” i jej dwóch konkretnych przejawów, czyli poetyckiego slamu i spotkania autorskiego. Rozważając to zagadnienie, trudno poprzestać na wniosku, iż dokumentalna kamera, towarzysząc slamowej rywalizacji lub spotkaniu z pisarzem, musi ograniczyć swój udział wyłącznie do nieskomplikowanej funkcji archiwizacyjnej. Analiza wybranych przykładów (warto od razu dodać - katalog filmowych tytułów, uosabiających sformułowane rozpoznania, nie jest bogaty) dowodzi, że wspomniany „styk” zawiera w sobie potencjał znacznie szerszy: dokument potrafi skutecznie uchwycić choćby unikalną dramaturgię zdarzenia, jego semantykę wpisaną nie tylko w słowo, ale i obraz, kryje on w sobie też niemałe możliwości interpretacyjne. Innymi słowy, jeśli ujmować filmowy dokumentalizm jako "dodatek” do literackiego zdarzenia, to tylko ze świadomością tych nie zawsze oczywistych, lecz istotnych znaczeniowo implikacji.
\end{abstract}




\section{d o k u m e n t a li z m}

\section{slam poetycki}

\section{OBRAZ}

\section{autor}

\section{kultura literacka}

literatura

\section{NOTA O AUTORzE:}

Piotr Pławuszewski - dr, pracownik Katedry Filmu, Telewizji i Nowych Mediów Uniwersytetu im. Adama Mickiewicza w Poznaniu. Jego zainteresowania badawcze koncentrują się przede wszystkim wokół teorii/praktyki kina dokumentalnego oraz historii filmu polskiego. Autor monografii twórczości Władysława Ślesickiego (w druku); współredaktor tomu Pogranicza dokumentu (Poznań 2012) oraz monograficznego numeru pisma „Images. The International Journal of European Film, Performing Arts and Audiovisual Communication" (t. XIV, 2014); publikował m.in. w „Images”, „Kinie”, „Kwartalniku Filmowym”, „Pleografie” i „Ekranach”. 